\title{
Preparation, Characterization and Antibacterial Effect of Chitosan Nanoparticles against Food Spoilage Bacteria
}

\author{
Abdullah A. Alarfaj \\ Department of Botany and Microbiology, College of Science, King Saud University, Riyadh, Saudi Arabia.
}

\begin{abstract}
Fresh cut fruits and vegetables spoiled by number of bacterial pathogens. In this experiment the low cost, nontoxic and pollution free chitosan nanoparticles were prepared in the laboratory level, characterized by FTIR, XRD and SEM and confirmed the presence of nanoparticles. Various concentrations of nanoparticles $(10 \mu \mathrm{g}, 20 \mu \mathrm{g}, 50 \mu \mathrm{g}, 100 \mu \mathrm{g}$ and $150 \mu \mathrm{g})$ were prepared and used to investigated the antibacterial activity against one positive (Bacillus $\mathrm{sp}$ ) and one negative bacteria (pseudomonas $\mathrm{sp}$ ) respectively. The results showed that zone of inhibition against Bacillus sp and Pseudomonas sp were noted at $50 \mu \mathrm{g}, 100 \mu \mathrm{g}$ and $150 \mu \mathrm{g}$ concentrations respectively. These results suggested that chitosan nanoparticles can be used as effective growth inhibitors for food spoilage microorganisms. It is confirmed that this pollution free low cost technology is suitable for arresting food spoilage bacteria effectively. Hence, the present study indicated that the non-toxic chitosan nanoparticles may be considered as a food preservative. Hence this preliminary study which will create further research in this new field.

Keywords: Antimicrobial Activity, Chitosan nanoparticles, Food spoilage, Bacterial pathogens, characterization.
\end{abstract}

*Correspondence: aalarfajj@ksu.edu.sa

(Received: 26 December 2018; accepted: 11 February 2019)

Citation: Abdullah A. Alarfaj, Preparation, Characterization and Antibacterial Effect of Chitosan Nanoparticles against Food Spoilage Bacteria, J Pure App/ Microbiol., 2019; 13(2): 1273-1278. doi: 10.22207/JPAM.13.2.70

C The Author(s) 2019. Open Access. This article is distributed under the terms of the Creative Commons Attribution 4.0 International License which permits unrestricted use, sharing, distribution, and reproduction in any medium, provided you give appropriate credit to the original author(s) and the source, provide a link to the Creative Commons license, and indicate if changes were made. 


\section{INTRODUCTION}

Food materials particularly fruits and vegetables are very essential food commodities all over the world. Because it provides essential dietary fibers, minerals and vitamins for human health (Sharma et al., 1998). So, keeping fruits and vegetables fresh ensures a good supply of vitamins, minerals and also increases the table value of such products. At the same time these are the most perishable agricultural producers. Due to lack of proper storage methods after harvesting nearly more than $30 \%$ of food (fruits and vegetables) materials are unfit for consumption. According to Kader, 1992 and Aworth and Olorunda, 1981 there are $20-50 \%$ fresh tomato has been loss (20-50\%) in tropical country during harvesting, transportation and consumption. Chelkowski, 1991 reported that total world grain production (10 to $30 \%$ ) has been lost after harvest. The World Health Report, 2002, stated that in worldwide the diseases such as Ischemic heart diseases (31\%) and stroke (11\%) only because of low consumption of fruits and vegetable intake by reason of lack of appropriate storage and processing facilities. The post-harvest handling (food storage) which not only extent the life of fruits and vegetables but also increase their period of availability and the market value of the crops (Kim, 2006). Fruit and vegetables are highly susceptible to microbial contamination due to their neutral pH (Madden, 1992). Nearly $15 \%$ of fruits and vegetables are perishable at the time of post harvested only because of the action of bacterial, fungal and mold. (Workneh and Osthoff, 2010). Brackett, 1992 stated that the microbial population which determine the quality of the food and consumer safety during storage. So that the growth rate of the micro-organisms (bacteria and fungi) that cause post-harvest rots spoilage of vegetables are roughly of equal importance. To avoid the above said problem, some physical process such as freezing, chilling, modified atmosphere packaging etc., and use of antimicrobials have been used to control microbial growth (Davidson 2001). On the other hand some chemical is used as an antimicrobial agent and they are considered as food additives.

But most of the results indicate that the antimicrobial effect of chemical compound is ineffective against some microorganisms and also which create some side effect to the consumer after consumption. So we are in need of a cost-effective and inexpensive method of food preservation. Therefore, low cost preservation methods are needed to increase antimicrobial effectiveness without side effect to the consumer and it should be generally recognized as safe (GRAS).

Keep in our mind, in order to fulfill the above said constrains in the present study the biofunctional food additive and non-toxic chitosan nanoparticles was consider for carrying out antimicrobial study. (Rhoades and Roller 2000; Sebti et al., 2005) Moreover in 2007 USFDA recognized the chitosan nanoparticles are admitted as generally as safe (GRAS). Worldwide (Japan, Korea, England, Italy, Portugal and United States) these nanoparticles are marketed as food additive (Novack et al., 2003). These nano-particles can be synthesized by deacetylation of crustacean shells, chitin contains $\beta$-1, 4-linked 2-amino-2deoxy- $\beta$-D-glucose. Helander et al., 2001 reported that chitosan nanoparticles effectively acted against some Gram-negative bacteria such as $E$. coli, Pseudomonas aeruginosa and S. typhimurium. Shahidi et al., 1999; No et al., 2007 studied the properties and applications of chitosan nanoparticles and their derivatives in food storage.

In the present study is food spoilage causing bacteria such as Bacillus spp. and Pseudomonas spp. were used to study for antimicrobial assays using chitosan nano-particles as antimicrobial agents. Well diffusion assay method was used to quantify the zone of inhibition. The aim of the present study is to find out the antibacterial effect of chitosan nanoparticles against food spoilage causing bacteria using well diffusion method. The present study will help better utilization of nano-particles for application of food preservation in future.

\section{MATERIALS AND METHODS \\ Preparation of chitosan nanoparticles}

The ionic gelation method was performed for preparation of chitosan (CS) nanoparticles. 3 $\mathrm{mg} / \mathrm{mL}$ of chitosan was dissolved in $1 \%$ acetic acid solution and $2 \mathrm{mg} / \mathrm{mL}$ of Tri polyphosphate (TPP) was dissolved in distilled water. CS nanoparticle suspension was prepared by $5 \mathrm{~mL}$ TPP solution $(2 \mathrm{mg} / \mathrm{mL}$ ) solution was dropped into $10 \mathrm{~mL} \mathrm{CS}$ solution under magnetic stirring $(1000 \mathrm{rpm})$ at 
room temperature. In order to further crosslinking of nanoparticles the prepared suspension was kept stirring for $30 \mathrm{~min}$. Finally CS nanoparticles were collected by centrifugation at 5,000 rpm and kept under freeze drier for 1 day at $-40^{\circ} \mathrm{C}$.

\section{Characterization of Chitosan nanoparticles}

In order to find out the morphology and size observations for the prepared nanoparticles the experiments such as FTIR, XRD and SEM were performed.

\section{FTIR analysis}

Spectrum GX-1, PerkinElmer, USA was used to perform FTIR analysis. There was 200 $\mathrm{mg} \mathrm{KBr}$ mixed with a small quantity of prepared nanoparticles and made as pallets. It was used to FTIR analysis in the spectral region of 4000-400 $\mathrm{cm}^{-1}$. ( Kumirska et al., 2010)

\section{Scanning Electron Microscopy (SEM)}

The size and the morphology of the prepared chitosan nanoparticles were examined using SEM. A small amount of prepared chitosan nanoparticles were kept on an SEM stub and it was placed in the scanning electron microscopy (SEM) Chamber and the photo micrographic image was taken at acceleration voltage of 20KV.

\section{$\mathrm{X}$ - Ray powder diffraction (X-RD)}

To confirm the amorphous nature of CS nanoparticles, X-RD pattern (Bruker, D-8 advance) was performed at the voltage of $20 \mathrm{kV}$ and the diffraction pattern was determined in the area 20 $<2$.

\section{Preparation of test inoculums}

The food spoiled organisms such as Bacillus sp. and Pseudomonas sp were collected from Department of Biology, College of Science, Al-Zulfi, Majmaah University, Majmaah- 11952, Riyadh region, Kingdom of Saudi Arabia. Both Bacterial cultures were sub-cultured onto nutrient agar medium and incubated overnight at $37^{\circ} \mathrm{C}$. Then inoculated both bacterial into $10 \mathrm{ml}$ sterile Mueller Hinton broth ( $\mathrm{MHB}$ ) respectively and incubated overnight at $37^{\circ} \mathrm{C}$ and the both bacterial suspensions were adjusted to 0.5 McFarland Standard $\left(1 \times 10^{8} \mathrm{CFU} / \mathrm{ml}\right)$. This $0.5 \mathrm{McF}$ arland cultures were s used for antibacterial test.

Evolution of antibacterial activity Agar well diffusion method (Perez et al., 1990)

Mueller-Hinton Agar plates were prepared and $10 \mu \mathrm{l}\left(10^{8} \mathrm{CFU} / \mathrm{ml}\right)$ of test culture was swapped on the surface of the plate using a sterile swab. Six mm wells were prepared using sterile cork borer. There were five different concentrations of chitosan nanoparticles $(10 \mu \mathrm{L}, 20 \mu \mathrm{L}, 50 \mu \mathrm{L}, 100 \mu \mathrm{L}$ and $150 \mu \mathrm{L}$ ) solution were poured into each well. It was allowed for 10 minutes to the diffusion of the chitosan nanoparticles on agar plates. All plated were inoculated at $37^{\circ} \mathrm{C}$ for 24 hours and then zone of inhibition (in $\mathrm{mm}$ ) was measured. .

\section{RESULT AND DISCUSSION \\ Characterization of the prepared nanoparticles SEM analysis}

SEM images confirmed the formation of spherical shaped nano structure (Fig. 1). It is the influence of the gelation agent. This result well correlated with the previous reports chitosan nanoparticle formation. The images also confirmed that their shape was fine and of homogenous size.

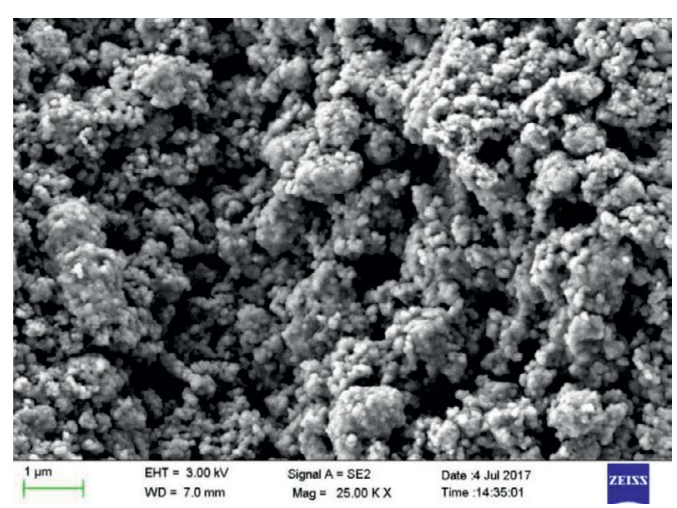

Fig. 1. SEM images of chitosan nanoparticles

\section{FTIR Analysis}

In Fig. 2 Chitosan showed its $\mathrm{O}-\mathrm{H}, \mathrm{C}-\mathrm{H}$, $\mathrm{C}-\mathrm{C}$ stretching, $\mathrm{N}-\mathrm{H}$, and $\mathrm{C}-\mathrm{O}$ vibrations at 3423 $\mathrm{cm}^{-1}, 2919 \mathrm{~cm}^{-1}, 1525 \mathrm{~cm}^{-1}, 1151 \mathrm{~cm}^{-1}$, and 1363 $\mathrm{cm}^{-1}$ respectively. The peak is confirms the chitosan originality was retained after the nanoparticle formation.

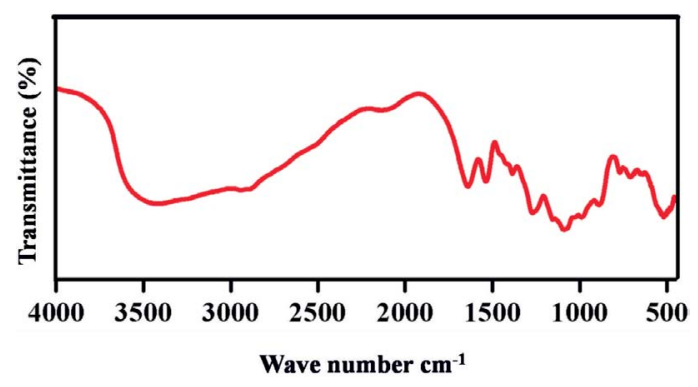

Fig.2. FTIR spectrum of Chitosan nanoparticle 
Table 1. Antibacterial activity of chitosan nanoparticles against food spoilage pathogens Bacillus sp. and Pseudomonas sp.

\begin{tabular}{cccc}
\hline S.N. & $\begin{array}{c}\text { Nanoparticles } \\
\text { concentration } \\
\text { (in } \mu \mathrm{g})\end{array}$ & $\begin{array}{c}\text { Zone of inhibition } \\
\text { (in mm) }\end{array}$ \\
\cline { 3 - 4 } & & $\begin{array}{c}\text { Bacillus } \\
\text { sp. }\end{array}$ & $\begin{array}{c}\text { Pseudomonas } \\
\text { sp. }\end{array}$ \\
\hline 1 & 10 & - & - \\
2 & 25 & - & - \\
3 & 50 & 10 & - \\
4 & 100 & 14 & 12 \\
5 & 150 & 18 & 19 \\
\hline
\end{tabular}

Note: '-' no zone of inhibition.

\section{XRD Analysis}

The Fig. 3 shows that the XRD pattern of CS powder. It gives the peak around $2 \theta$ at 11,20 which corresponds to crystal forms. The XRD pattern shows the amorphous nature of the chitosan nanoparticles.

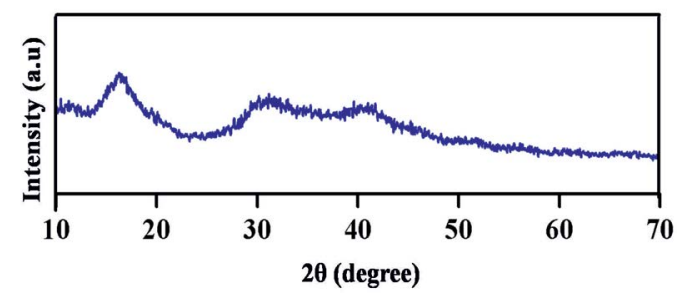

Fig. 3. XRD spectrum of Chitosan nanoparticles

\section{Antibacterial activity}

To find out the effect of antibacterial activity against two food pathogens such as Bacillus spp and Pseudomonas spp using chitosan nanoparticles, agar well diffusion method was used (Table 1 and Fig. 4-5). The table shows that activity against tested bacteria. 10 and $25 \mu \mathrm{g}$ of chitosan nanoparticles did not show activity against Bacillus sp. and Pseudomonas sp. 50 $\mathrm{gg}$ of chitosan nanoparticles were inhibited the growth of Bacillus sp. $(10 \mathrm{~mm})$ but not Pseudomonas sp, 100 and $150 \mu \mathrm{g}$ of chitosan nanoparticles showed more zone of inhibition against both tested bacteria Bacillus sp (14 and $18 \mathrm{~mm}$ ) and Pseudomonas sp (14 and $18 \mathrm{~mm}$ ) respectively.

The results indicated that the higher concentrations of 100 and $150 \mu \mathrm{g}$ of chitosan nanoparticles were inhibited the growth of Bacillus sp and Pseudomonas sp effectively. The maximum zone of inhibition was observed at 150 $\mu \mathrm{g}$ against Bacillus sp. (18 $\mathrm{mm})$ and Pseudomonas sp. $(19 \mathrm{~mm})$.

The reason no bacterial inhibition at low concentration might be has less binding capacity with bacterial cells. Papineau et al., 1991. Sudarshan et al., 1992 also reported that the polycationic chitosan at a lower concentration ( 0 . $2 \mathrm{mg} / \mathrm{ml}$ ), does probably bind to the negatively charged bacterial surface to cause agglutination. The maximum antibacterial activity was shown only above $150 \mu \mathrm{g}$ concentration of nanoparticles. In conclusion, chitosan nanoparticles have a wideranging of activity against a panel of bacteria

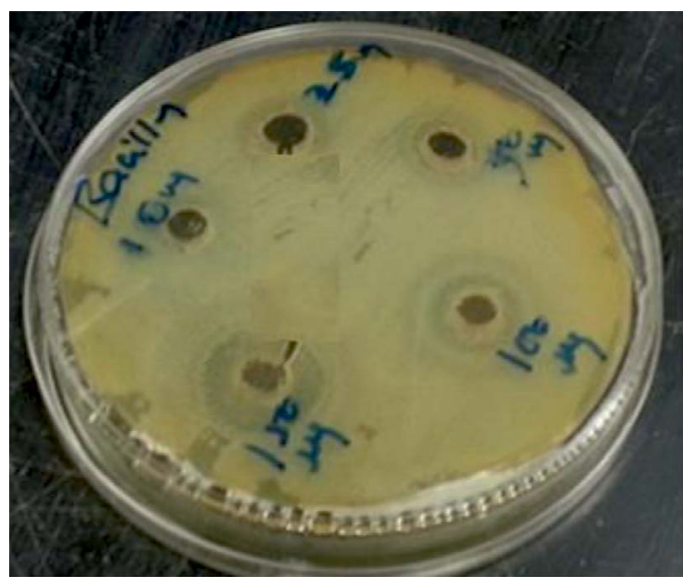

Fig. 4. Zone of Inhibition of chitosan nanoparticles against tested bacteria Bacillus spp.

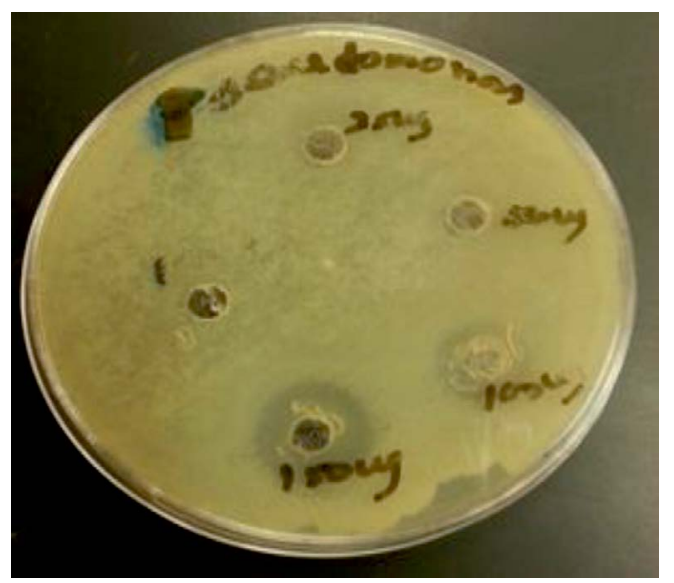

Fig. 5. Zone of Inhibition of chitosan nanoparticles against tested bacteria Pseudomonas spp. 
Bacillus sp. and Pseudomonas sp. responsible for the most common bacterial spoilage in fruits and vegetables.

The chemical and structural properties chitosan NPs attributed the antimicrobial activity against Bacillus sp. and Pseudomonas spp. Even different mechanisms have been proposed (Rabea et al., 2003) for the antimicrobial action of chitin, chitosan, one of the main reason is that its positively charged amino group which interacts with negatively charged microbial cell membranes and damage the cell by leakage of proteinaceous and other intracellular constituents (Shahidi et al., 1999). Begin and Van Calsteren 1999; Helander et al., 2001 reported that polycationic structure of chitosan such as lipopolysaccharides and proteins of the membrane cell surface which disrupt the integrity of the bacterial cell outer membrane resulting bactericidal (Helander et al., 2001).

Previously the same kind of study has been evaluated by several researches. Li et al., 2008 investigated that $0.10 \mathrm{mg} / \mathrm{mL}$ Chitosan solution inhibited the growth of Xanthomonas pathogenic bacteria. Gonzleza Aguilar et al., (2005) reported that incorporation of chitosan of low and medium molecular weight at concentrations of $1 \%$ and $2 \%(\mathrm{w} / \mathrm{v})$ arrested the growth of mesophilic bacteria and fungi in coated fresh-cut papayas (stored at $5^{\circ} \mathrm{C}$ for 15 days). Chien et al., (2007) found that chitosan coating applied sliced mango (0. $5 \%, 1 \%$, and $2 \%(\mathrm{w} / \mathrm{v})$ preserved for long time at $6^{\circ} \mathrm{C}$. Rhoades and Roller (2000) reported that yeasts cells were completely inactivated when addition of $0.03 \%(\mathrm{w} / \mathrm{v})$ chitosan to apple-elder flower juice $(\mathrm{pH} 3.3)$ during $13 \mathrm{~d}$ of storage at $7^{\circ} \mathrm{C}$.

\section{CONCLUSION}

In the present study nontoxic chitosan nanoparticles were prepared effectively in the laboratory level and characterized. The prepared nanoparticles showed more antibacterial effect at lower concentrations against two tested bacterial species such as Bacillus sp. and Pseudomonas sp. Hence this present study indicated that these low cost and nontoxic nanoparticles will be very useful and applicable as a preservative agent in the future. Still this study has some limitations and further study must be need. However this initial step provides a chance to carry out further research in future.

\section{ACKNOWLEDGMENTS}

The author would like to extend his sincere thanks to RSSU, the Deanship of Scientific Research at King Saud University for its similarity checking and editing. The author would like to extent his sincere acknowledgments to the Department of Biology, College of Science, Al-Zulfi, Majmaah University, Majmaah- 11952, Riyadh region, Kingdom of Saudi Arabia for bacterial identification.

\section{FUNDING}

None

\section{DATA AVAILABILITY}

All datasets generated or analyzed during this study are included in the manuscript.

\section{ETHICS STATEMENT}

The article does not contain any studies with human participants or animals performed by the author.

\section{REFERENCES}

1. Aworth OC, Olorunda AO. Towards reducing postharvest losses of perishable fruits and vegetables in Nigeria. In the proceeding of the National Conference in Agriculture. Port Harcourt. Nigeria. 1981.

2. Begin A, Van alsteren MR. Antimicrobials Ims produced from chitosan. Int. J. Biol. . Macromol., 1999; 26: 63-67.

3. Brackett R. Shelf- stability and safety of fresh produce as influence by sanitation and disinfection. J. Food. Protection., 1992; 55: 808-814.

4. Chelkowski J. Cereal grain mycotoxins, fungi and quality in drying and storage. Drying. Technol., 1993;11: 411-412..

5. Chien PJ, Sheu F, Yang FH. Effects of edible chitosan coating on quality and shelf life of sliced mango fruit. J. Food. Eng., 2007;78; 225-229.

6. Davidson PM. Chemical preservatives and natural antimicrobial compounds. In: Doyle MP, Beuchat LR, Montville TJ, editors. Food microbiology: fundamentals and frontiers, $2^{\text {nd }}$ edition Washington, D.C.: ASM Press. 2001; 593-627.

7. Gonzalez Aguilar GA, Monroy-Garcla IN, GoycooleaValencia F, Daz-Cinco ME, AyalaZavala, JF. Cubiertas comestibles de quitosano. Una alternativa para prevenir eldeterioro microbiano y conservar la calidad de papayas frescas cortadas.. 2005; 121-33.

8. Helander IM, Nurmiaho-Lassila EL, Ahvenainen R, Rhoades J, Roller S. Chitosan disrupts the barrier properties of the outer membrane of Gram-negative bacteria. Int. J. Food. Microbiol., 2001;71:.235-44.

9. Kader AA. Postharvest Biology and Technology; an overview, In: A.A. Kader (eds) Postharvest Technology of Horticultural Crops. University of California division 
of Agriculture Natural Resources, Publication 3311. California, USA. 1992: 15-20

10. Li BX, Wang R, Chen W, Huangfu, Xie G. Antibacteria activity of chitosan solution against Xanthomonas pathogenic bacteria isolated from Euphorbia pulcherrima. Carbohydr. Polym., 2008;72: 287-292.

11. Madden JM. Microbial pathogens in fresh produceThe regulatory perspective. J Food. Protec., 1992; 55: 821-823.

12. Novack K, Cupp MJ, Tracy TS. Chitosan. In: Cupp MJ, Tracy TS, editors. Dietary supplements. Toxicology and clinical pharmacology. Totowa, N.J.: Humana Press Inc. 2003; 33-40.

13. Papineau AM, Hoover DG, Knorr D, Farkas DF. Antimicrobial effect of water-soluble chitosans with high hydrostatic pressure. Food. Biotechnol., 1991;5: 45-57.

14. Rabea EI,. Badawy MET, Stevens CV, Smagghe G, Steurbaut W. Chitosan as Antimicrobial Agent: Applications and Mode of Action. J. .Biomacromol., 2003; 4:1457-1465.

15. Rhoades J, Roller S. Antimicrobial actions of degraded and native chitosan against spoilage organisms in laboratory media and foods. Appl. Environ. Microbiol., 2000; 66:80-86.

16. Sebti I, Martial-Gros A, Carnet-Pantiez, Grelier S, Coma V. Chitosan polymer as bioactive coating and film against Aspergillus niger contamination. J. Food. Sci., 2005; 72:100-104.

17. Shahidi F, Kmil A, Arachi A, You-Jim J. Food applications of chitin and chitosans. Trends. Food. Sci. Technol.1999; 10:.37-51.

18. Sharma, N, Mashoor Alam M. Post-harvest diseases of Horticultural perishable. 1st edition 1998, Published by International book distributers, Charb aga, Luknow, India.

19. Sudarshan NR, Hoover DG, Knorr D. Antibacterial action of chitosan. Food. Biotechnol., 1992;6: 257272.

20. USFDA U.S Food and Drug Administration. 2007. Summary of all GRAS notices. Available from: http:// www.cfsan.fda.gov/rdb/opagras.html. Accessed Jul 7, 2007.

21. Workneh TS, Osthoff G. A review on integrated agrotechnology of vegetables, African J. of Biotechnol., 2010; 9: 9307-9327.

22. Kumirska J, Czerwicka M, Kaczyoski Z, Bychowska A, Brzozowski K, Thyming J, Stepnowski P. Application of Spectroscopic Methods for Structural Analysis of Chitin and Chitosan. J. Mar. Drugs., 2010; 8:1567-1636.

23. Perez C, Pauli M, Bazerque P. An Antibiotic Assay by Agar Well Diffusion Method. Acta Biologiae. Et. Medicinae. Experiment., 1990;15: 113-115. 